\title{
KINERJA KEUANGAN, KOMISARIS INDEPENDEN, GENDER DIVERSITY DAN FINANCIAL DISTRESS
}

\section{Nabila Aprilia Aldama ${ }^{1}$ Farida Titik Kristanti ${ }^{2}$}

Article history:

Submitted: 24 Juni2021

Revised: 30Juli 2021

Accepted: 6 Agustus 2021

\section{Keywords:}

Financial Distress; Gender Diversity; Independent Commissioners; Leverage: Liquidity;

\section{Kata Kunci:}

Financial Distress; Gender Diversity; Komisaris Independen; Leverage;

Likuiditas;

\section{Koresponding: \\ Fakultas Ekonomi dan Bisnis Telkom University, Jawa Barat, Indonesia Email: nabilaaldama9@gmail.com}

\section{Abstract}

Large institutions have a huge influence on the economy in Indonesia, especially property, realestate, construction and building institutions because it has a significant effect on Gross Domestic Product or GDP and labor absorption. Therefore, institutions must maintain performance and financial condition in order to avoidfinancial di stress. The purpose of this research is to find out the correlation of liquidity, leverage, size of institutions, independent commissioners, and gender diversity to financial distress by using quantitative techniques with secondarydata. The population in this research is property, real estate, construction and building institutions listed on the Indonesia Stock Exchange in 2014-2019, using purposive sampling techniques obtained 35 samples. The analysis method used by analysts a log istic regression by using IBM SPSS 25 application asa statistical test tool and hypothesis. The results obtained from this research show that variable liquidity, leverag $e$, agencysize, independent commissioners, and gender diversity are simultaneously correlated to financial distress. Leverage variables are separatelynegativelycorrelated tofinancial distress while liquidity variables, company sizes, independent commissioners and gender diversity are not partially correlated to financial distress.

\begin{tabular}{|c|}
\hline Abstrak \\
\hline 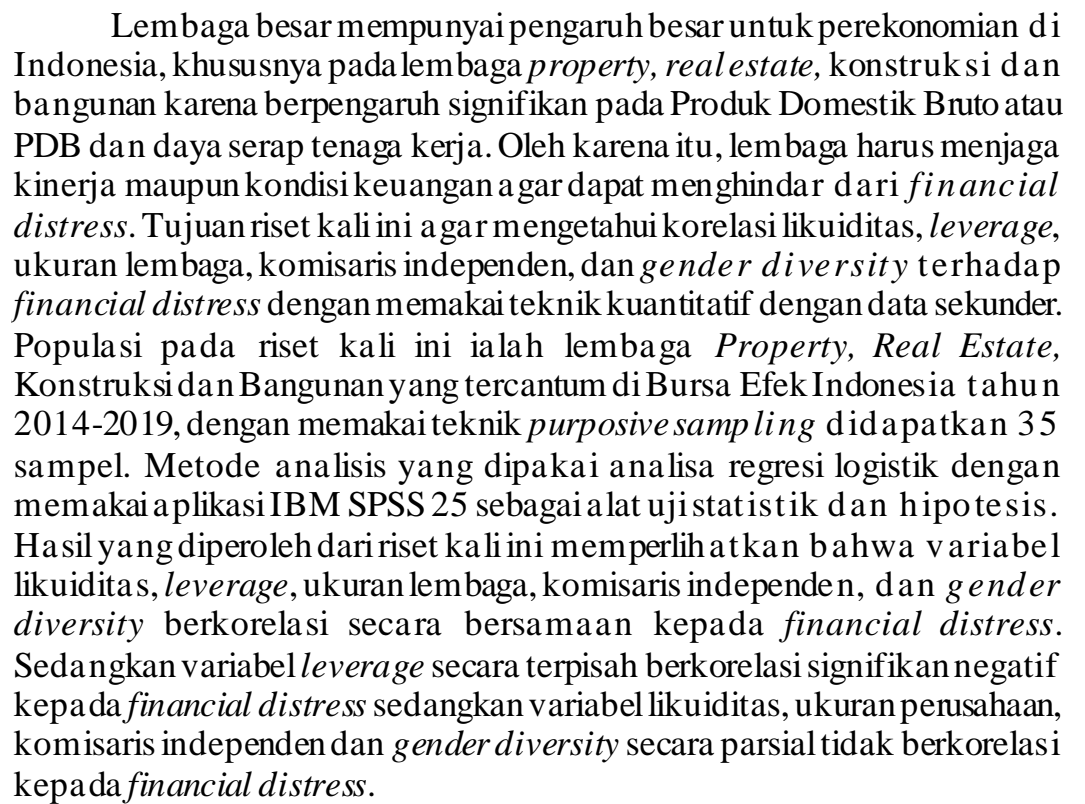 \\
\hline
\end{tabular}

Fakultas Ekonomidan Bisnis Telkom University, Jawa Barat, Indonesia ${ }^{2}$ 


\section{PENDAHULUAN}

Perusahaan property, real estate dan Konstruksi Bangunan berdampak besar terhadap perekonomian Indonesia, seperti yang dikatakan oleh Menteri Keuangan RI Sri Mulyani pada 27 November 2020 bahwa sektor perumahan memiliki dampak besar bagi produk domestik bruto (PDB) dan memiliki berantai pada penyerapan tenaga kerja yang signifikan. Pengeluaran dari sektor ini dapat menambah PDB sebesar 0,6\% sampai dengan 1,4\% dan dapat menyerap tenaga kerja sebesar 4,23 juta orang.

Tujuan didirikan sebuah perusahaan adalah untuk mendapatkan laba, namun kadang perusahaan tidak dapat mencapai tujuan tersebut. Banyak faktor yang menyebabkan tujuan tersebut tidak tercapai, salah satunya yaitu persaingan antar usaha, hal tersebut mengharuskan perusahaan untuk memberikan banyak inovasi baru namun apabila bisnis perusahaan tidak dapat berjalan dan bersaing dengan perusahaan lain maka akan meyebabkan penurunan kinerja perusahaan baik dalam kinerja operasi perusahaan maupun kinerja keuangan perusahaan. Apabila kinerja keuangan perusahaan terus-menerus mengalami penurunan hal itu dapat membuat lembaga mendapatkan keuangan yang sulit atau financial distress. Lembaga wajib mengetahui keadaan kesulitan keuangan perusahaan sejak dini karena kesulitan keuangan biasanya terjadi sebelum kebangkrutan (Permana et al., 2017).

Financial distress ialah keadaan dimana lembaga mengalami keuangan yang tidak sehat atau mengalami krisis (Moleong, 2018). Berdasarkan Tyaga \& Kristanti, (2020) financial distress dapat terjadi dikarenakan lembaga tidak sanggup dalam menyeimbangkan kinerja finansial sehingga menjadi penyebab kerugian keuangan operasional maupun keadaan rugi bersih pada tahun yang berjalan. Menjaga kestabilan keuangan dapat dilakukan dengan cara mempertahankan investor yang berinvestasi dalam perusahaan, maka manajemen perlu mengungkapkan secara sukarela mengenai informasi perusahaan baik yang bersifat rahasia yang didasari oleh teori sinyal (Muflihah, 2017). Sinyal-sinyal yang disampaikan dapat membahas sinyal keberhasilan maupun sinyal kegagalan yang diungkapkan kepada pemakai laporan keuangan (Primasari, 2018). Hal tersebut akan membantu pemakai laporan keuangan dalam proses pengambilan keputusan. (Hal tersebut membantu pemakai laporan keuangan dalam proses pengambilan keputusan.) Perihal ini mampu membantu pemakai laporan finansial dalam proses pembuatan putusan.

Financial distress dapat dilakukan pengukuran dengan memakai banyak kriteria, diantara nya ialah earning per share (EPS). Mengukur financial distress dapat EPS, ketika EPS sebuah lembaga bernilai negatif dapat disimpulkan bahwa lembaga tersebut ada pada dalam keadaan keuangan yang sulit (finacnial distress) seperti pada penelitian Kristanti et al., (2016) EPS memperlihatkan keuntungan entitas yang diperoleh pada waktu yang berjalan dan memperlihatkan kinerja perusahaan tersebut baik pada masa lalu dan masa depan. Apabila perusahaan menunjukkan EPS bernilai negatif maka dapat dinilai bahwa perusahan tersebut mengalami pertumbuhan yang tidak baik dan dapat mengarah pada kondisi distress.

Berdasarkan Gambar 1. dapat dilihat bahwa perusahaan property, real eastate, konstruksi dan bangunan yang mempunyai EPS bernilai negatif jumlahnya fluktuatif dari tahun ke tahun, jumlah tertinggi pada tahun 2019 yaitu sebanyak 11 perusahaan. Perusahaan yang mengalami kondisi EPS bernilai negatif berturut-turut setiap tahunnya akan berkemungkinan lembaga tersebut dalam keadaan financial distress bahkan dapat mengarah ke kondisi default, namun juga bisa menjadi hal menguntungkan jika hal tersebut dijadikan sebagai "early warning" dan perusahaan dapat mengelola dan mengatasi permasalahan yang ada (Kristanti, 2019). 


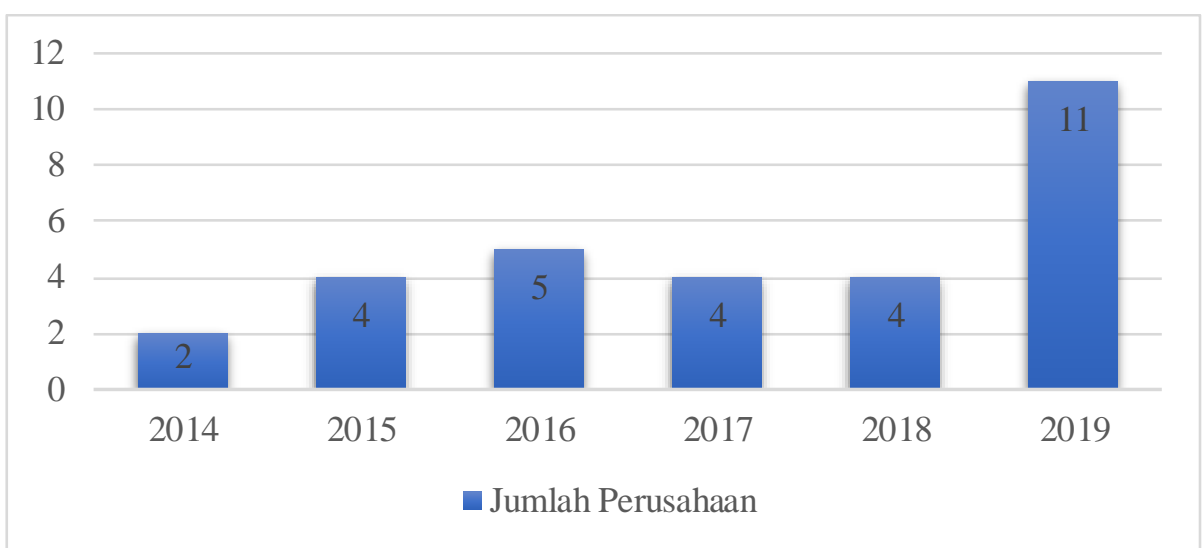

Sumber: BursaEfek Indonesia(diolaholehpenulis) 2021

Gambar 1.

EPS Perusahaan Property, Real Estate, Konstruksi dan Bangunan BEI 2014-2019

Rasio likuiditas ialah rasio dipakai untuk melakukan pengukuran financial distress. Rasio likuiditas mampu menggambarkan kapasitas lembaga dalam melunasi hutang lancarnya (Kristanti, 2019). Indikator yang dipakai dalam pengukuran likuiditas pada riset kali ini ialah current ratio. Current ratio (CR) atau rasio lancar merupakan kemampuan lembaga untuk melunasi utang jangka pendeknya dengan cara memakai aktiva lancar (Sujarweni, 2016). Apabila lembaga dapat membiayai hutang jangka pendeknya dengan baik maka perusahaan berkemungkinan kecil mendapatkan kesulitan pada keuangannya (financial distress). Riset yang telah dilaksanakan untuk melihat korelasi rasio likuiditas kepada financial distress yaitu oleh Zhafirah, (2019) dan Masdupi et al., (2018) yang menunjukkan hasil negatif signifikan.

Rasio leverage menggambarkan bagaiamana perusahaan mampu memenuhi hutangnya, baik hutang jangka pendek atau jangka panjang. Menurut Tyaga \& Kristanti, (2020) rasio leverage sangat cocok untuk mengukur financial distress karena kondisi keuangan perusahaan dapat dilihat dari bagaimana kemampuan perusahaan dalam membayar kewajibannya, apabila lembag tidak sanngup membayar atau mencukupi hutangnya maka lembaga akan menuju kepada kondisi pailit. Oleh karena itu, ketika leverage perusahaan tinggi ada kemungkinan perusahaan tidak dapat membayar kewajibannya yang memicu terjadinya financial distress. Indikator yang dipakai dalam pengukuran leverage pada riset ini adalah debt to assets ratio (DAR). Riset yang sudah dilakukan oleh Moleong, (2018) menunjukkan hasil leverage berkorelasi positif yang signifikan kepada financial distress.

Selain rasio keuangan di atas, ukuran perusahaan (size) dapat digunakan mengukur financial distress Tujuan ukuran perusahaan (size) untuk memberikan gambaran besar atau kecilnya sebuah lembaga yang ditunjukkan dengan jumlah harta, jumlah penjualan, dan rata-rata jumlah harta (Wati, 2019). Ukuran perusahaan (size) dapat mencerminkan kondisi keuangan sebuah perusahaan, oleh karena itu ukuran perusahaan mempunyai keterkaitan dengan financial distress, semakin besar suatu perusahaan maka dapat dinilai bahwa kinerja keuangan yang ada di dalam perusahaan adalah baik dan dapat menghindar dari kondisi financial distress (Wati, 2019). Riset yang telah dilaksanakan oleh Kristanti \& Effendi, (2017) dan Zhafirah, (2019) profitabilitas mempunyai korelasi negatif signifikan kepada financial distress.

Faktor lain yang bisa memengaruhi financial distress adalah tata kelola lembaga atau corporate governance, tata kelola lembaga yang baik akan mendorong dewan direksi dan manajer lembaga untuk mencapai tujuan sebuah lembaga, variabel corporate governance yang akan dipakai pada riset kali ini yaitu komisaris independen. Berdasarkan KNKG (2006) komisaris independen ialah dewan komisaris yang tidak memiliki hubungan spesial dengan manajemen, anggota dewan komisaris lainnya, dan stake holder yang lain, komisaris independen tidak mempunyai kepentingan bisnis lain 
untuk memengaruhi pengambilan keputusan yang akan dilakukannya, komisaris independen hanya bekerja untuk kepentingan perusahaan dalam mencapai tujuan perusahaan. Komisaris independen mempunyai fungsi untuk mengawasi kinerja manajemen yang berkaitan dengan keuangan, dengan sifat independensi yang dimiliki maka dapat memperkecil kemungkinan kecurangan keuangan yang terjadi, sehingga tingkat proporsi komisaris independen yang tinggi dapat mengurangi pemicu tejadinya financial distress. Riset yang telah dilaksanakan oleh Kristanti \& Isynuwardhana, (2018) memperlihatkan bahwa komisaris independen korelasi negatif signifikan kepada financial distress.

Gender diversity akan memengaruhi proses pengambilan keputusan, karena pemimpin wanita cenderung lebih berhati-hati dan suka menolak risiko dibandingkan dengan pemimpin laki-laki (Kristanti, 2012). Hal tersebut akan berpengaruh pada konsep high risk high return, dengan banyaknya pemimpin wanita dalam perusahaan akan memperkecil kemungkinan risiko yang akan terjadi namun dengan sedikit risiko yang diambil maka perusahaan juga akan kecil dalam mendapatkan return. Dengan return yang kecil juga dapat memicu terjadinya financial distress. Riset yang telah dilaksanakan oleh Kristanti \& Isynuwardhana, (2018) memperlihatkan bahwa gender diversity memiliki korelasi positif signifikan kepada financial distress.

Berdasarkan teori yang telah dipaparkan, didapatkan kerangka pemikiran pada riset kali ini yaitu seperti dibawah ini:

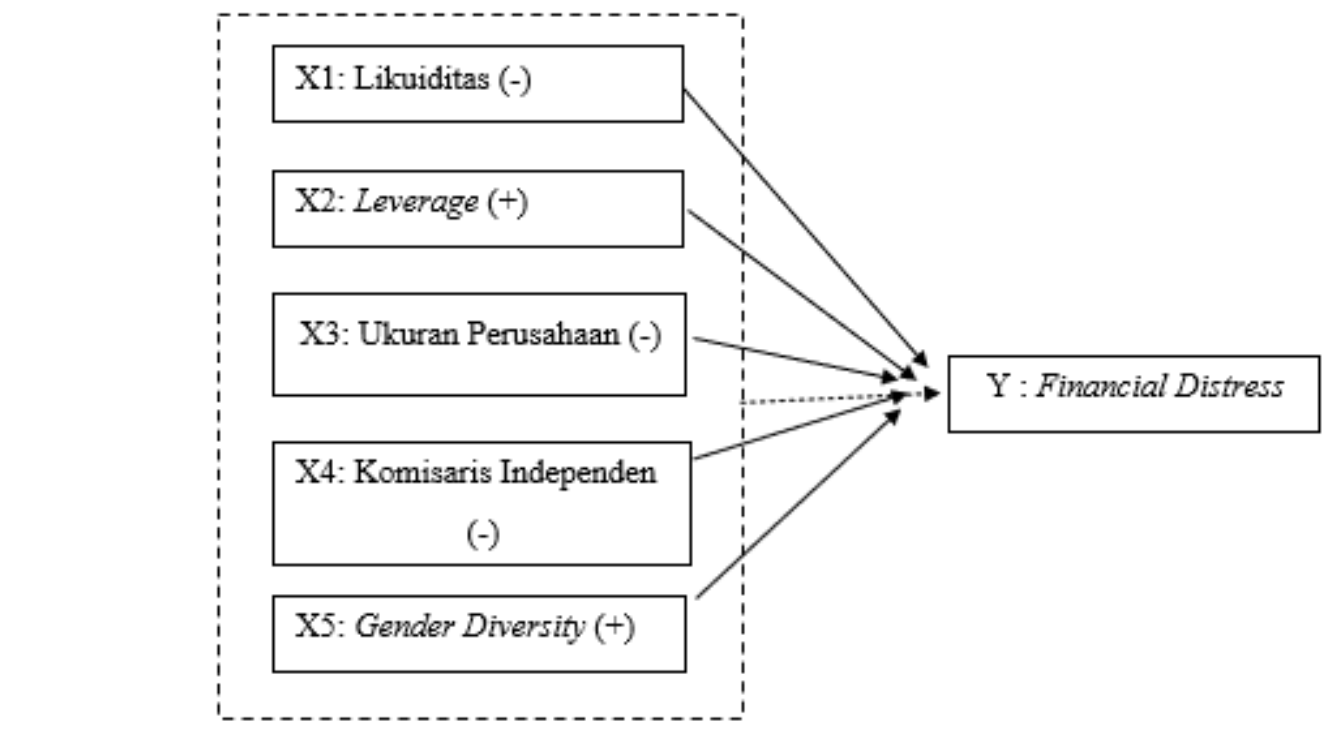

Sumber: diolah olehpenulis 2021

\section{Gambar 2. \\ Kerangka Pemikiran}

Keterangan:

Korela si Simultan :

Korelasi Parsial:

\section{METODE PENELITIAN}

Metode regresi logistik dipakai pada riset kali ini. Analisa regresi logistik pada dasarnya sesuai dengan analisa diskriminan, tetapi dikarenakan variabelnya gabungan antara skala rasio dan skala nominal menyebabkan asumsi multivariate normal distribution tidak dapat diubah (Ghozali, 2016). Memakai populasi lembaga property, real estate, konstruksi dan bangunan yang tercantum pada BEI pada periode tahun 2014-2019, dengan teknik purposive sampling dan kriteria: 1) Lembag a sektor property, real estate, konstruksi dan bangunan yang tercantum di BEI pada periode tahun 20142019. 2) lembaga property, real estate, konstruksi dan bangunan yang tercantum di BEI yang 
menerbitkan laporan keuangan tahun 2014-2019 diperoleh 210 data yang terdiri atas 35 perusahaan dengan periode penelitian selama enam tahun dari 2014-2019.

Tabel 1.

\section{Teknik Pengambilan Sampel}

\begin{tabular}{clc}
\hline No & \multicolumn{1}{c}{ Kriteria Sampel } & Jumlah \\
\hline 1. & $\begin{array}{l}\text { Perusahaan property, real estate, konstruksi dan bangunan y ang } \\
\text { terdaftar di Bursa Efek Indonesia tahun 2014-2019 }\end{array}$ & 82 \\
2. & $\begin{array}{l}\text { Perusahaan } \text { property, real estate, konstruksi dan bangunan y ang } \\
\text { terdaftar di Bursa Efek Indonesia yang tidak menerbitkan la poran } \\
\text { keuangan tahun 2014-2019 }\end{array}$ & \\
\hline \multicolumn{1}{c}{ Jumlah Sampel } & 35 \\
\hline Sumber: BursaEfek Indonesia(diolaholehpenulis) 2021
\end{tabular}

Metode yang dipakai pada riset ini ialah analisa regresi logistik, dengan persamaannya seperti dibawah ini:

$\operatorname{Ln} \frac{F D}{1-F D}=\alpha+\beta 1 \mathrm{CR}+\beta 2 \mathrm{DAR}+\beta 3 \mathrm{SIZE}+\beta 4 \mathrm{KI}+\beta 6 \mathrm{GD}$.

Keterangan:

$\begin{array}{lll}\boldsymbol{L n} \frac{\boldsymbol{F D}}{\mathbf{1 - F D}} & : \text { Financial distress. (variabel dummy } 0=\text { perusahaan mengalami EPS } \\ \alpha & : \text { positif, dan } 1=\text { perusahaan yang mengalami EPS negatif) } \\ \beta 1 \beta 2 \beta 3 \beta 4 \beta 5 & : \text { Konstanta } \\ \text { CR } & : \text { Likuiditas memakai current ratio } \\ \text { DAR } & : \text { Levergae memakai debt to assets ratio } \\ \text { KI } & : \text { Komisaris Independen } \\ \text { GD } & : \text { Gender Diversity } \\ \varepsilon & : \text { Kesalahan/error }\end{array}$

Pertama, menghitung variabel dependen yaitu financial distress dengan menjadikan variabel dummy yaitu apabila EPS bernilai positif ditandai dengan 0 yang artinya lembaga tidak dalam kondisi financial distress, dan apabila EPS bernilai negatif ditandai dengan 1 yang artinya lembaga berada dalam kondisi financial distress.

Kedua, Hosmerand Lameshow's Goodness of Fit Test dipakai sebagai uji coba kesesuaian model regresi. Model dikatakan fit dan dapat menjelaskan nilai observasinya apabila antara model dan data tidak ada perbedaan, ditunjukkan apabila nilai Hosmerand Lameshow's Goodness of Fit Test lebih dari 0,05, dan apabila nilai Hosmerand Lameshow's Goodness of Fit Test sama atau kurang dari 0,05 maka terdapat perbedaan yang signifikan pada data sehingga tidak baik digunakan dikarenakan model tersebut tidak dapat memberikan prediksi nilai pengamatannya.

Ketiga, model fit dinilai untuk mencari tahu ada tidaknya perbedaan kemungkinan hasil prediksi dengan hasil observasi menggunakan statistik pada fungsi likelihood. IBM SPSS menghasilkan dua hasil $-2 \log L$ yang pertama sebelum memasukkan variabel independen hanya konstanta saja (Block 0: Beginning Blog) dan yang kedua setelah memasukkan variabel independen 
dan konstanta (Block 1: method = enter). Apabila hasil -2LogL lebih kecil dari hasil -2LogL pertama berarti penambahan variabel independen dinilai model fit dengan data yang dihipotesiskan. Model $\log$ likelihood regresi logistik memiliki kemiripan dengan sum of error pada model regresi, dimana semakin kecil nilai log likelihood berarti model regresi yang dipakai semakin baik.

Keempat, menggunakan koefisien determinasi untuk mencari kemampuan variabel terikat dalam menjelaskan variabilitas variabel bebas. Besar kecilnya nilai koefisien dalam regresi logistik ditampilkan oleh Nagelkerke $R$ Square. Nilai R2 Nagelkerke dapat ditampilkan seperti angka R2 dalam regresi berganda.

Kelima, pengujian simultan menggunakan Nagelkerke $R$ Square. Untuk memberi kepastian nilai Nagelkerke $R$ Square memiliki variasi dari nol (0) hingga satu (1) dengan cara angka Cox dan Snell's $R^{2}$ dibagi dengan nilai maksimalnya. Hasil dapat dikatakan berpengaruh signifikan apabila nilai sig lebih dari 0,05 dan dinyatakan tidak berkorelasi signifikan apabila nilai kurang dari 0,05.

Keenam, untuk melakukan uji coba pada tiap variabel apakah mempunyai pengaruh atau tidak dengan menggunakan uji parsial logit regresi. Penentuan tingkat signifikasi pada uji parsial adalah 0,05 yang mana jika signifikansi memiliki nilai kurang dari 0,05 maka variabel tersebut berkorelasi secara terpisah kepada variabel bebas, begitupun sebaliknya jika nilai signifikansi lebih besar dari 0,05 mempunyai arti variabel terikat tidak memiliki pengaruh secara parsial pada variabel bebas.

\section{HASIL DAN PEMBAHASAN}

Teknik analisa yang digunakan pada penelitian ini adalah teknik analisis regresi logistik. Pengujian pertama yang dilakukan adalah menguji keseluruhan model (overall model fit) untuk mengetahui apakah model yang dihipotesiskan sudah fit dengan data atau belum dengan cara membandingkan nilai -2 Log Likelihood sebelum dan sesudah di tambah dengan variabel bebas. Tujuan dari pengujian ini untuk menunjukkan apakah penambahan variabel bebas dapat memperbaiki data atau tidak (Ghozali, 2016).

Tahap selanjutnya dilakukan pengujian kelayakan model dengan menggunakan pengujian hosmer and lemeshow test dengan memperhatikan nilai goodness offit yang diuku r dengan menggunakan nilai Chi-Square. Data dinilai dapat digunakan apabila nila

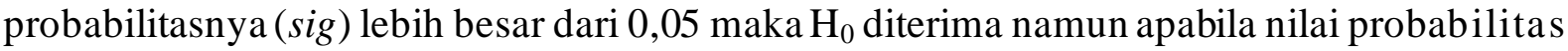
(sig) kurang dari 0,05 maka $\mathrm{H}_{0}$ ditolak, karena model tidak dapat digunakan karen a terd ap at perbedaan yang signifikan antara model dengan nilai data sehingga model tidak dapat memprediksikan nilai data nya (Ghozali, 2016).

Pengujian selanjutnya setelah menguji kelayakan model adalah menguji koefisien determinasi dengan model summary yang ditunjukkan oleh nilai Negelkerke $R$ Square untuk menilai berapa besar kemampuan variabel independen dalam menjelaskan variabilitas variabel dependen. Pengujian simultan bertujuan untuk melihat apakah variabel likuiditas, leverage, ukuran perusahaan, komisaris independen, dan gender diversity secara bersamasama berpengaruh secara simultan terhadap financial distress. Pengujian secara simultan pada analisis regresi logistik dilihat pada tabel omnibus test of model coefficients, dilihat dari nilai sig apabila nilainya lebih kecil dari 0,05 maka $\mathrm{H}_{0}$ ditolak dan $\mathrm{H}_{\mathrm{a}}$ diterima yang berarti varibel independen secara bersama-sama berpengaruh simultan terhadap variabel dependen, dan apabila nilai sig lebih besar dari 0,05 maka $\mathrm{H}_{0}$ diterima dan $\mathrm{H}_{\mathrm{a}}$ ditolak yang berarti varibel independen secara bersama-sama tidak berpengaruh simultan pada variabel dependen (Ghozali, 2016).

Pengujian secara parsial bertujuan untuk mengetahui pengaruh masing-masing variabel independen terhadap variabel dependen, dengan cara membandingkan tingkat 
signifikansi sebesar 0,05 dengan nilai signifikansi yang dihasilkan, apabila nilai signif ikansi yang dihasilkan lebih besar dari 0,05 maka $\mathrm{H}_{0}$ diterima dan $\mathrm{H}_{\mathrm{a}}$ ditolak, dan apabila nilai signifikansi yang dihasilkan kurang dari 0,05 maka $\mathrm{H}_{0}$ ditolak dan $\mathrm{H}_{\mathrm{a}}$ ditetima.

Tabel 2.

Hasil Analisis Statistik Deskriptif

\begin{tabular}{|c|c|c|c|}
\hline & \multicolumn{2}{|c|}{ Mean } & \multirow{2}{*}{ Std Deviation Statistic } \\
\hline & Statistic & Std Error & \\
\hline $\mathrm{Y}$ & 0,14 & 0,024 & 0,346 \\
\hline $\mathrm{X}_{1}$ & 2769,8000 & 218,73360 & 3169,75103 \\
\hline $\mathrm{X}_{2}$ & 418,9333 & 13,25338 & 192,05979 \\
\hline $\mathrm{X}_{3}$ & 27641,8000 & 218,90220 & 3172,19419 \\
\hline $\mathrm{X}_{4}$ & 372,7762 & 9,10674 & 131,96916 \\
\hline $\mathrm{X}_{5}$ & 150,6000 & 11,16935 & 161,85933 \\
\hline
\end{tabular}

Sumber: SPSS 25 data diolah penulis, 2021

Tabel 2 menunjukkan variabel $\mathrm{X}_{1}$ (likuiditas), $\mathrm{X}_{3}$ (Ukuran Perusahaan), $\mathrm{X}_{5}$ (Gender Diversity) memiliki nilai std deviasi lebih besar dibanding dengan nilai mean, berarti variabel likuiditas, ukuran perusahaan, dan gender diversity memiliki data yang heterogen atau bervariasi. Variabel $\mathrm{X}_{2}$ (leverage) dan $\mathrm{X}_{4}$ (Komisaris Independen) memiliki nilai std deviasi lebih kecil dibanding dengan nilai mean, berarti variabel leverage dan komisaris independen memiliki data yang homogen atau berkelompok.

Tabel 3.

Hosmer and Lemeshow Test

\begin{tabular}{cccc}
\hline Step & Chi-Square & df & Sig. \\
\hline 1 & 11,055 & 8 &, 199 \\
\hline
\end{tabular}

Sumber: SPSS 25 data diolah penulis, 2021

Hasil Hosmer and Lemeshow Test ditunjukkan pada Tabel 3 memiliki Chi-Square senilai 11,055 dan signifikansi 0,199 yang mana lebih besar dari 0,05 berarti hipotesis yang dimiliki tidak dapat ditolak lalu model dikatakan fit dan sanggup memprediksi nilai observasinya.

Tabel 4.

Omnibus Test of ModelCoefficients

\begin{tabular}{ccc}
\hline Chi-Square & $d f$ & Sig. \\
\hline 21,682 & 5 &, 001 \\
21,682 & 5 &, 001 \\
21,682 & 5 &, 001
\end{tabular}

Sumber: SPSS 25 data diolah penulis, 2021

Omnibus Tests of Model Coefficients ditunjukkan pada Tabel 4 dan memiliki nilai Chi-Square model 21,682 dengan nilai probabilitas sig model sejumlah 0,001 yang kurang dari 0,05, berarti secara bersama variabel independen dapat memengaruhi variabel dependen. 
Tabel 5.

Model Summary

\begin{tabular}{ccc}
\hline -2 Log Likelihood & Cox \& Snell R Square & Negelkerke R Square \\
\hline 146,944 &, 098 &, 178 \\
\hline
\end{tabular}

Sumber: SPSS 25 data diolah penulis, 2021

Nilai Negelkerke $R$ Square ditunjukkan pada Tabel 5 yang memiliki nilai sejumlah 0,178, nilai tersebut menunjukkan besarnya kemampuan variabel untuk menjabarkan variabel dependen. Dengan nilai Negelkerke $R$ Square sebesar 0,178 berarti kemampuan menjelaskannya sebesar $17,8 \%$ dan terdapat faktor di luar model yang menjelaskan variabel dependen sebesar 82,2\%.

Tabel 5.

Variables in the Equation

\begin{tabular}{lcl}
\hline & $\boldsymbol{B}$ & Sig. \\
\hline $\mathrm{X}_{1}$ &, 059 &, 333 \\
$\mathrm{X}_{2}$ & $-3,640$ &, 011 \\
$\mathrm{X}_{3}$ &,- 035 &, 574 \\
$\mathrm{X}_{4}$ &,- 640 &, 713 \\
$\mathrm{X}_{5}$ & 1,800 &, 162 \\
\hline
\end{tabular}

Sumber: SPSS 25 data diolah penulis, 2021

Berdasarkan Tabel 5, menunjukkan bahwa variabel $\mathrm{X}_{1}$ (likuiditas) tidak berkorelasi dengan financial distress yang ditunjukkan dengan nilai signifikansi ,333 lebih besar dari 0,05. Sesuai dengan penelitian (Kristanti \& Isynuwardhana, 2018) dan (Tyaga \& Kristanti, 2020) dalam penelitiannya yang menyatakan tidak ada korelasi yang signifikan pada likuiditas dan financial distress, yang artinya status likuiditas lembaga yang tinggi tidak berpengaruh pada kemungkinan keuangan distress yang terjadi di lembaga.

Variabel $\mathrm{X}_{2}$ (leverage) berkolerasi terhadap financial distress dengan nilai signifikansi 0,011 yang lebih kecil dari 0,05 dan nilai koefisien sebesar -3,640 yang menunjukkan bahwa variabel leverage berkorelasi negatif terhadap financial distress. Hasil penelitian ini didukung dengan penelitian yang dilakukan oleh (Masdupi et al., 2018) dan (Opitalia \& Zulman, 2019), yang menemukan bahwa leverage berkorelasi negatif dengan financial distress, yang berarti kondisi leverage yang tinggi akan membantu perusahaan menghindari kondisi financial distress.

Variabel $\mathrm{X}_{3}$ (Ukuran Perusahaan) menunjukkan hasil tidak berkorelasi dengan financial distress diperlihatkan dengan nilai signifikansi sebesar 0,965 lebih besar dari 0,05. Didukung dengan riset yang telah dilaksanakan oleh (Pertiwi, 2018) dan (Tyaga \& Kristanti, 2020) yang memperoleh hasil variabel ukuran perusahaan tidak berkorelasi signifikan pada financial distress, yang berarti bahwa besar kecil lembaga tidak mempengaruhi terjadinya financial distress.

Variabel $\mathrm{X}_{4}$ (Komisaris Independen) tidak berkorelasi kepada financial distress yang diperlihatkna dengan hasil nilai signifikansi sejumlah 0,713 lebih besar dari 0,05. Hasil ini didukung dengan riset (Zhafirah, 2019) dan (Dianova \& Nahumury, 2019) yang menyatakan hasil komisaris independen tidak berkorelasi signifikan kepada financial distress yang bermakna bahwa besar kecil proporsi dewan komisaris independen tidak memengaruhi kondisi terjadinya financial distress. 
Variabel $\mathrm{X}_{5}$ (Gender Diversity) tidak berkorelasi kepada financial distress yang diperlihatkan dengan nilai signifikansi dengan nilai 0,162 yang mana lebih besar dari 0,05 didukung dengan riset (Almarita \& Kristanti, 2020) yang menyatakan besar atau kecilnya direksi wanita yang berada di dalam jajaran direksi tidak mempengaruhi terjadinya financial distress karena hanya ada beberapa perusahaan yang menyatakan ada direksi wanita di dalam jajaran direksinya.

\section{SIMPULAN DAN SARAN}

Menurut hasil riset yang diperoleh pada lembaga property, real estate, konstruksi dan bangunan yang terdafar di BEI tahun 2014-2019 diperoleh kesimpulan variabel likuiditas, ukuran perusahaan, komisaris independen, dan gender diversity tidak berkorelasi signifikan kepada financial distress, yang mempunyai arti kondisi financial distress tidak terpengaruhi oleh variabel-variabel tersebut. Namun, variabel leverage mampu mempengaruhi keadaan terjadinya financial distress karena pada hasil rise ini variabel leverage menunjukkan hasil yang signifikan ke arah negatif terhadap financial distress.

Atas kesimpulan yang telah dipaparkan, penulis memberikan saran kepada pihak perusahaan untuk menjaga kondisi leverage perusahaan atau tingkat kewajiban perusahaan karena hal tersebut dapat memicu terjadinya kondisi financial distress. Selanjutnya saran untuk peneliti agar lebih banyak menambah populasi dan sampel yang lebih beragam pada sektor yang lain, dan juga menggunakan variabel yang lain seperti mekanisme good corporate governance serta variabel makroenomi seperti tingkat suku bunga, inflasi dan nilai tukar.

\section{REFERENSI}

Almarita, S., \& Kristanti, F. T. (2020). Analisis Good Corporate Governance dan Ukuran Perusahaanterhadap Financial Distress. 14(2), 155-170.

Dia nova, A., \& Nahumury, J. (2019). Investigating the Effect of Liquidity, Leverage, Sales Growth and Good Corporate Governance on Financial Distress. Journal of Accounting and Strategic Finance, 2(2), 143-156. https://doi.org/10.33005/jasf.v2i2.49

Ghoza li, I. (2016). Aplikasi Analisis Multivariate dengan Program IBM SPSS 23 (Delapan). B a dan Peerbitan Universitas Diponegoro.

Kristanti, F. T. (2012). Penggunaan LeveragePa da Perusahaan: Perbedaan Antara Ceo Pria Dan Wanita. Ju rnal Siasat Bisnis, 16(2), 243-257.https://doi.org/10.20885/j sb.vol1 6.iss2.art9

Kristanti, F. T. (2019). Financial Distress (Teori dan Perkemban gannya dalam Konteks Indonesia). Malang : Intelegensia Media.

Kristanti, F. T., \& Effendi, N. (2017). A survivala nalysis of indonesian distressed company u sing cox hazard model. International Joumal of Economics and Management, 11(1), 155-167.

Kristanti, F. T., \& Isynuwardhana, D. (2018). How long are The Survival Time in the Industrial Sector of Indonesian Companies? International Journal of Engineering \& Technology, 7(4.38), 856. https://doi.org/10.14419/ijet.v7i4.38.27560

Kristanti, F. T., Rahayu, S., \& Huda, A. N. (2016). The Determinant of FinancialDistress on Indonesian Family Firm. Procedia - Social and Behavioral Sciences, 219(10), 440-447. https://doi.org/10.1016/j.sbspro.2016.05.018

Ma sdupi, E., Ta sman, A., \& Davista, A. (2018). The Influence of Liquidity, Leverage and Profitability on Financial Distress of Listed Manufacturing Companies in Indonesia. 57(Piceeba), 223-228. https://doi.org/10.2991/piceeba-18.2018.51

Moleong, L. C. (2018). Pengaruh Real Interest Rate dan Leverage Terhadap FinancialDistress. Open Journal Systems, 30(1), 71-86.

Muflihah, I. Z. (2017). Analisis Financial Distress Perusahaan Manufaktur Di Indonesia dengan Regresi Logistik. Majalah Ekonomi, XXII(2), 254-269.

Permana, R. K., Ahmar, N., \& Djadang, S. (2017). Prediksi Fina ncialDistress Pa da Peru sahaan Manufakt ur Di Bursa Efek Indonesia. Esensi: Jurnal Bisnis Dan Manajemen, 7(2), 149-166. 
https://doi.org/10.15408/ess.v7i2.4797

Pertiwi, D. A. (2018). Pengaruh Rasio Keuangan, Growth, Ukuran Perusahaan, dan Inflasi Terhadap Fin an cial Distress di Sektor Pertambangan Yang Terdaftar DI Bursa Efek Indonesia (B EI) Periode 20 12-2016. Jurnal Ilmu Manajemen $\quad$ (JIM), https://jurnalmahasiswa.unesa.ac.id/index.php/jim/article/view/24314

Primasari, N. S. (2018). Ana lisis Altman Z-Score, Springate, dan Zmijewski sebagai Signaling Financial Distress. Accounting and Management Journal, 1(1), 23-43. https://doi.org/10.33086/amj.v1i1.70

Sujarweni, V.W. (2016). Metodologi Penelitian dan Bisnis. Yogyakarta, Pustaka Baru Press.

Tyaga, M. S., \& Kristanti, F. T. (2020). Analisis Survival Dalam Memprediksi Kondisi Financial Distress. Buletin Studi Ekonomi, 25(1), 112. https://doi.org/10.24843/bse.2020.v25.i01.p07

Wati, N. L. (2019). Model Corporate Social Responsibility (CSR) (Momon(ed.)). Myra Publisher.

Zhafirah, A. (2019). Analisis Determinan Financial Distress. Analisis Determinan Financial Distress, 7(1), 195202. https://doi.org/10.17509/jrak.v7i1.15497 